Inga B. Kuźma*

Alicja Piotrowska**

\title{
Support Spaces. An Anthropological Approach to Selected Design Solutions in Support Institutions
}

\begin{abstract}
The article presents conclusions from research on the space of support institutions. The authors use mainly the tools of cultural anthropology and proxemics. The authors used three examples known to them from their projects on homeless people and those endangered by other types of social exclusion: BSZMKI from Budapest, one of the Krakow St. Padre Pio Aid Centers and Gdansk House, located in the Dolne Młyny area. The authors show how these buildings are constructed, how places are created there with a special character, to what extent the idea of support, which every institution pursues by implementing a specific program, goals and missions, translates into spatial and aesthetic relations and what kind of ethics it produces. They also show the possibilities of anthropological and proxemic approach to decipher the "hidden curriculum" embodied by each institution, also in a spatial context. According to the authors, this kind of analysis of material data along with the interpretation of the rules of using the building and spatial order, which is observed inside the institution, may support reflection on the course of support offered in institutions run by specific organizations.
\end{abstract}

Keywords: proxemics, institution, support, homelessness, exclusion.

\footnotetext{
* Uniwersytet Łódzki, Centrum Innowacji Społecznych.

** Uniwersytet Łódzki, Centrum Innowacji Społecznych.
} 


\title{
Przestrzeń wsparcia. Ujęcie antropologiczne wybranych rozwiązań projektowych $w$ instytucjach wsparcia
}

\begin{abstract}
Abstrakt
Artykuł przedstawia wnioski z badań na temat przestrzeni instytucji wsparcia. Autorki korzystają głównie z narzędzi antropologii kulturowej i proksemiki. Autorki bazują na trzech przykładach znanych im z prowadzonych przez nie projektów na temat sytuacji osób bez domu i zagrożonych innymi rodzajami wykluczenia społecznego: BSZMKI z Budapesztu, jednego z Centrów Pomocy krakowskiego Dzieła im. Św. O. Pio oraz gdańskiego Domu na Dolnych Młynach. Autorki pokazują, jak owe budynki są skonstruowane, w jaki sposób powstają tam miejsca o szczególnym charakterze, na ile idea wsparcia, której hołduje każda z instytucji, realizując określony program, cele i misje, przekłada się na stosunki przestrzenne i estetyczne oraz jaki rodzaj etyki wytwarza. Ukazują także możliwości podejścia antropologiczno-proksemicznego dla rozszyfrowania „ukrytego programu” wcielanego przez każdą instytucję, także w kontekście przestrzennym. Według autorek tego rodzaju analiza danych materialnych wraz z interpretacją zasad używania budynku i porządku przestrzennego, który jest przestrzegany wewnątrz instytucji, mogą wesprzeć refleksję nad przebiegiem wsparcia oferowanego w placówkach prowadzonych przez określone organizacje.
\end{abstract}

Słowa kluczowe: proksemika, instytucja, wsparcie, bezdomność, wykluczenie.

\section{Introduction}

The purpose of this work is to show how space may be used for tasks completed in social support institutions - it is about arrangement of space and an architectonic design; how the physicality and materiality of places (see Nawratek 2013; Trzeciak 2018) influence the aid process and how socio-cultural concepts of aid are realized in specific institutional spaces. In our considerations, we will use concepts developed by Edward T. Hall, Mary Douglas, Erving Goffman, and Michel Foucault, and we will look from the viewpoint of cultural anthropology, which is our main specialization. The issues presented in the work combine cultural anthropology and proxemics. However, they also refer to disciplines where aid and social support as well as education lie within the priority area of research (Mendel 2006; Sadon-Osowiecka 2015; Sikorski 2013; Skałbania, Gretkowski 2016).

We are going to describe three field case studies pertaining to centres supporting homeless people: two Polish ones and a Hungarian one. These are centres which provide support to people without homes. The institutions have different histories and different legal statuses. That translates into the manner of financing, which, in turn, often has an important influence on the possibilities for decisionmakers who establish, run, and maintain the organization and on the space for its 
operations. As is often the case, one authority finances an institution, another body runs it, and it is someone else completely that designed the space the institution uses. That issue attracted our attention during the realization of two projects, i.e. Development of a model of functioning, management, and financing of the Łódź Centre of Social Services as a part of a pilot project titled "Development of the model of revitalising urban areas in a selected area of the City of Łódź - stage 2" and "Women and Homelessness", Erasmus+1.

What the institutions selected by us have in common is providing aid in the crisis of homelessness. They also fit into specific cultural patterns of perceiving homelessness and aid. Those institutions realize such patterns literally, that is to say physically, by giving them the form of buildings and rooms, by arranging space, which is the materiality referred to above.

The work consists of five parts. After this introduction, the second part presents theoretical foundations related to our understanding of a support institution and to the proxemic idea of space, which, as we believe, is an important variable for social actions and relationships. The third part recalls key concepts of thinking about the manners of operation of aid institutions according to the panopticon and total institution paradigm. The fourth part describes selected field cases. In the fifth part, we summarize our discussion.

\section{Institutions and space}

We propose that social support institutions should be understood as units with various specializations and with the purpose to provide aid to those who need it, including to ensure their well-being. Institutions of that type may even include peer groups or primitive groups (e.g. the concept of a family as an institution), but, in the context of this work, we think of institutions as places created intentionally, the main purpose of which is to provide support in specific life situations to specific groups of people. That aid or support is provided in a special building or room.

The space occupied by an institution is often constructed specially for that purpose from the architectonic point of view (considering e.g. requirements of universal design ${ }^{2}$ ) to pursue the goals of the institution as well as possible. Therefore, institutions of that type include centres providing all-day, day-time, night-time, or immediate aid; they reach out to groups selected due to their health, type of diseases, or special needs, including mental and physical ones, with

\footnotetext{
1 Detailed descriptions of the projects are available at https://www.bmszki.hu/en/erasmus2/aboutproject; $\quad$ https://rewitalizacja.uml.lodz.pl/rewitalizacja/wybrane-projekty-rewitalizacji/projektpilotazowy-ii-2017-2019/.

2 Ref. to the website dedicated to equal availability in the context of universal design within a government website http://www.niepelnosprawni.gov.pl/art,54,projektowanie-uniwersalne, where valid legal acts and recommendations may be found, from EU legal acts and recommendations to ones adopted for the needs of various associations and related to compliance with universal design principles.
} 
consideration of age, material situation, and living conditions (e.g. homelessness). In such places, support may be received not only in the form of satisfaction of basic biological needs, but also in the form of advice, including advice for development or improvement of status quo. These are also places which offer aid in emergencies. In general, such places are open for people dependant on others in various ways and to a various extent.

Our interests focus on cultural-social strategies and tactics which are translated into a specific spatial "text", ones used in places related to providing aid to people experiencing the crisis of homelessness.

Each person dealing with provision of support should ensure appropriate conditions for that, including spatial conditions. What does it mean? In search of an answer to that question, we turn to proxemics. Proxemics is an interdisciplinary science created by Edward T. Hall (e.g. 1976; 1987; ref. also to Hall and Hall 2001). That discipline studies the influence of people on their surroundings, which they form according to cultural standards and values, and vice versa, i.e. it studies how the type and nature (both aesthetics and ethics) of one's surroundings influence one's behaviour, contacts between people, including communication (cross-cultural communication and contacts as well), and perception of one's own body, values, dignity and social position. According to principles of proxemics understood anthropologically, "in (...) a socially-created space, what is important is (...) a functional factor. A space is not (...) created by accident but to reflect people's needs" (Cobel-Tokarska 2011: 48).

What is important, due to the tasks completed by support institutions and the social position of people who seek help there, the appearance and spatial order of such places, including the nature of their aesthetics related to specific ethics (see Piątkowska 2016), may enhance or weaken the aid activities. As Marta Cobel-Tokarska writes:

(...) one's position in the social structure and the assumed role of either a creator or a user conditions the relationship which will be established between a person and a space. The social dimension of a space, however, reflects hierarchies existing among people as well. Therefore, a better and worse, richer and poorer, safe and dangerous space exists as well as the centre and the peripheries, sacrum and profanum (Cobel-Tokarska 2011: 49).

According to our assumption, spaces where support is provided are not arranged only to meet formal criteria (i.e. construction or sanitary etc. ones), but through their spatial (cultural) order they also reflect an attitude to the idea of support, including to people who receive it. It is one of the contexts of a hidden curriculum existing in institutions.

The existence of such assumptions is shown by, among other things, the layout of rooms, their arrangement, distances, sizes, lighting, the use of space, the 
presence or absence of common spaces, and to what extent those are sociopetal or sociofugal places.

According to the division by Hall (1976), a sociofugal space is one where contacts, including conversations and eye contact, are brief and superficial, as the conditions are not favourable for them. They are also not helped by the interior design, i.e. too cool colours, high ceilings, lighting, loud sounds etc. Sociofugal spaces include halls, corridors, or waiting rooms in various institutions (which is even more emphasized by the linear arrangement of chairs, counters etc.) as well as lecturing rooms. A sociopetal space, on the other hand, is the opposite. It facilitates contacts, conversations, and relationships. It may not be too light or too dark; light is dispersed or directed to highlight important places. Furniture size is adapted to the density of people. Colours include pastel or toned down warm shades. The space is not overloaded or too empty, giving the impression of a sterile space. The arrangement of furniture enables people to make contact, e.g. seats are put at an angle to each other rather than in a straight line; they may also face each other. Pieces of furniture are arranged in small clusters which creates favourable conditions for gathering, making circles, including strangers. Furniture seems solid and sturdy; it is upholstered. Sociopetal spaces are also divided into smaller niches using walls, plants etc. to create corners, shelters, or safe spaces. For example, the effect of a sociopetal space may be achieved by lowering the ceiling.

The space and its interior design in the cultural-social aspect refer to a specific system of values and are related to the problem which is to be solved in the place concerned. Therefore, place and space are not inconsequential to the problem; they influence its perception and management, enhance various cultural judgements, e.g. concerning the issue of interest to us, i.e. provision of aid to the homeless, reasons for providing such aid, and the manner of providing it.

\section{Hidden curriculum and spatial organization of institutions in the context of support provided to people in the crisis of homelessness}

What was characteristic of former support institutions for people without homes was a kind of pressure, which was sometimes stronger and sometimes weaker, expressed in the form of official and informal rules (Bystroń 1970; Kępski 1993; Lipiński 2010; Mazur 1999; Raś 2011). Another tool having the same effect was the special organization of space; it was best if buildings fitted the spirit of control from the architectural point of view. As a result, panoptism reigned there. Foucault (1998) drew that idea from the model of a Panopticon of Jeremy Bentham from 1787. It was an architectural design used in prisons, shelters, hospitals, and schools, i.e. in institutions which nowadays are treated as providers of support. Bentham's design was supposed to work in places where it was important to 
maintain supervision over residents. The architectural solution included rooms with internal and external windows; the whole building was a rotunda with an inspection house in the centre. The guards staying in the inspection house were able to look through the windows into the rooms occupied by the residents. As a result, they could watch all residents at the same time and the life of the residents in all its aspects was visible and open to control (they would live as if on stage). As Bentham designed it, the guards were supposed to be invisible for the residents of the panopticon. As the residents did not know whether or when they were being watched, they would behave as if they were being monitored all the time. Therefore, they would "self-regulate their behaviour" and, as a result, they would become "guards for themselves" (Nowel-Śmigaj 2012: 27). That was the foundation on which the power of the observers over the observed grew.

Modern places where aid is provided to homeless people are not constructed according to Bentham's guidelines; however, the idea of access to the "clients", influencing their behaviour, making them visible, and watching/supervising over them still exists in many centres (Kuźma 2015). That may be explained as a need to provide protection and security, to offer better support, and be close to such people. Panoptism may exist in a formal aspect, i.e. as the right of staff to interfere in the manner of behaviour, being, or organization of the micro-space for residents of such centres or clients arriving to receive support. That type of authority watches them to observe any violations of the rules etc.

Panoptism is one of the (self-)control mechanisms characteristic of the system called by Goffman (2011) a total institution. He also believed that shelters and night shelters for the homeless are examples of such institutions. Total institutions are "places of stay and work for a great number of people in a similar situation, separated temporarily from the rest of society, and leading a formalized life" (ibidem: 11). What decides about their totality, is the degree of confinement. That means social isolation which affects people belonging to the institution, as they do not have possibilities of realizing their needs or potentials in full, or of entering into any type of interaction they want. The confinement of an institution is also symbolized with physical borders and barriers, such as gates, bars, fences etc. blocking access from the outside and closing people in from the inside.

Although shelters, night shelters, re-adaptation houses etc. for the homeless may be classified as total institutions, they are certainly not a pure type of such an institution. However, on their premises Borders between such fundamental activities as work, privacy (embodied by sleep for Goffman), and entertainment are broken, which is typical for total institutions. As Goffman believes, none of those spheres of life is realized normally according to an imposed schedule. They happen in separate places, with different people (ibidem: 16). However, in total institutions Borders between those spheres are eliminated. No one is alone in there; all residents are treated in the same or a similar way. Certain activities are usually performed following an imposed pattern; actions should end each time with 
a result pre-defined by a person who supervises order. In that way, a total institution follows its purpose.

The imposition upon residents to adopt specific attitudes and make specific gestures (which is visible, most of all, in the army, in prisons, and in religious orders) changes their self-esteem and self-perception (ibidem: 30, ref. to Kuźma 2015). That seems even more interesting in the context of institutions for people experiencing homelessness. Attitudes to such people in culture may be called specific; they are often treated as conditionally "own" who, however, have more in common with "strangers" as a result of losing their familiar attributes. Despite that, they require special treatment as "ex-own", i.e. they may be treated (often unconsciously and stereotypically) as deprived of properties and qualities which proved that they once met the criteria of normality which are met by others (ref. to Goffman 2005).

What is important, institutions providing aid to the homeless did not do it without conditions (and many of them still do not do it that way today); the flow of (tangible and intangible) support is controlled, structured according to a hierarchy, and measurable. That support may often be taken away or limited if a person who needs it goes beyond the criteria or fails to observe the rules. Such a person is disciplined by the "parametrization" of its properties (e.g. poverty or homelessness). They come to receive support and that infers anticipation and passivity. The institutions they turn to treat them, as a result, mostly as "petitioners" or "clients", i.e. people who are "served" by "being provided a service". What creeps into the relationship is clientelism and the language reflecting the relationship of a commercial exchange (Kuźma 2015).

If the institutions prefer the arrangement of a sociofugal space, which is typical for structures of total and panoptic institutions, it may be difficult to break the patterns of thinking about homelessness and the sense of aid. The FEANTSA document titled "Participation Guide. How to Share Power: FEANTSA Working Group for Participation" emphasizes that by stating that "introduction of participation is a sign of evolution in social work methods: from doing things for people to doing things with people", as

two fundamental ideas support such inclusion. The first one assumes that people requiring aid have the right to voice an opinion on the form of services they use and the care they receive. Moreover, their opinion is of fundamental importance as it is they who are recipients of those services (...). The second idea is the acceptance of the fact that the situation of people needing aid due to their e.g. physical or mental disability, makes it more difficult for them to become involved, voice their opinion, and have an influence on decisions having an effect on the functioning of the aid system, which is natural for others (Przewodnik partycypacji ... 2007). 
A similar observation related to the manner of organizing space for support and aid is made by researchers studying institutions dealing with people in the crisis of homelessness: "Spatial characteristics of shelter services refer to the methods of intervention and interaction within shelter, that are determined by physical structures of shelter" (Walsh, Beamer, Alexander, Shier, Loates, Graham 2010: 43), while "participatory design is an approach where stakeholders are involved in the design process" (Dickinson, Stafford, Klingenberger, Bicak, Boyd, Dreyer 2017: 54). Such an attitude is related to properties typical for User Experience and User-Centred Design, i.e. methods using techniques and methodologies fundamental for e.g. cultural anthropology (such as careful listening), which is interdisciplinary and related to participatory, community, or universal design (Basińska, Jeran 2016), which includes sensitivity to users' needs.

Breaking the patterns of functioning in space, which means, according to our assumptions, seeking alternative manners of arranging institutional space, is not easy if we agree with Mary Douglas that, in westernized culture, institutions have a very strong influence on the manner of thinking and they also consolidate the stereotypes which they repeat: "(...) an inability to assume a different point of view despite reasonable arguments results from control which institutions have over our processes of classification and legitimization" (Douglas 2011: xvi). Douglas believes that " $(. .$.$) the process of an institution becoming rooted is intellectual as well as$ economic and political. (...) To become legitimized, each type of an institution needs a rule which will conclude the institution's justification from reason and nature" (ibidem: 47). A reference to nature "naturalizes" institutions, i.e. "makes them natural", comprehensible through their nature. Douglas underlines that:

(...) similarities which bring beneficial social analogies, are arranged, most of all, to make social institutions legitimate; they are not for making conclusions on the material world. Moreover, efforts to strengthen weak social institutions by rooting them in nature will fail if someone discovers them. Therefore, the founders' analogies must remain hidden and the influence of the thinking style on the thinking world must remain secret. That does not mean that those analogies are based on accidental similarities (ibidem: 57).

So what does a similarity consist in? "There may only be one answer: a similarity is a property conferred to a set of various elements recognized as a certain category. It is institutions that decide about the similarity and that confer similarity to objects" (ibidem). As a result, it is easier to submit oneself to the authority and order of an institution which approves and fixes those rules and confers the status of a standard to them. In addition to that,

rules of an institution include past experiences and, as a consequence, they enable the prediction of what may be expected in the future. The more completely institutions encode expectations, the better they are able to control 
uncertainty, which makes conformism towards the institutional matrix increase. With such a degree of coordination, chaos and uncertainty vanish (ibidem: 50).

Therefore, institutions guarantee safety and comfort both to those who use them directly and to all others, as institutions are emanations of a certain "collective mind", i.e. shared knowledge or a community system of values, which is also reflected in their physical construction and spatial order.

\section{The spaces of homeless support institutions - selected cases (Budapest, Krakow and Gdansk)}

As we have already emphasized, on the symbolic and material levels institutions are embodiments of a specific, hidden, cultural-social curriculum. Spaces which are created in this manner may be called an environment and they have an effect on people. It is not determinism, but the influence of the specific parameters of the place, such as the layout and appearance of rooms, furniture arrangement and types, shape of the building, lighting etc., which were mentioned in the introduction. They are stimuli which bring specific reactions. They may influence the mood, the feeling of danger or isolation, the feeling of trust, freedom, equality, dependence, or submission to processes and procedures governing the place concerned (Hall, Hall 2001; Dymnicka, Rozmarynowska 2006).

Therefore, such places may single out and separate different categories of people by segregating them, due to functions (a client vs. a staff member) or due to the tasks and purposes of rooms, which is justified in many situations (in particular washing rooms, doctor's offices, dining rooms, changing rooms, therapy rooms, or diagnostic conversation rooms).

However, the lower the flexibility of a space is, which means the changeability of its tasks, and the weaker its sociopetal influence, the more fixed the division is between various groups of users of the place/institution in question. It may be assumed that such an institution follows the rule of hierarchy rather than the horizontal order of relationships, including with reference to the layer of contact between the groups. It may also be assumed that in an institution of that type, inclusion and a subjective approach to people coming to receive help are valuable to a small extent only.

Low flexibility is demonstrated by, e.g., a small number of places the purpose of which may be changed, e.g. transformation of a day room into a community meeting place or a staff supervision place or a place for a meeting with the local community, etc. No flexibility is reflected by a small number of shared spaces and spaces half-open to users, who are regular and internal, though diverse (i.e. with regard to clients of the place concerned e.g. to enable them to spend time there 
while waiting for their appointment or to spend their free time integrating with others in a free and non-imposed manner; with regard to the staff - to enable staff members to spend time together e.g. during breaks, and to be with clients in a less formal way).

Flexibility enables adaptation of needs to the environment. It may exist on many levels. (...) Changes resulting from evolution of needs are too costly to encode permanently or for a long-term according to pre-defined needs, possibilities and aspirations. Nowadays, changeability and adaptability have no limits (Dymnicka, Rozmarynowska 2006: 253-254).

\section{The Budapest Methodological Centre of Social Policy and its Institutions in Hungary}

During the project entitled Women and Homelessness, we were able to see how an aid institution for people in the crisis of homelessness located in Budapest operates. It is a public and state-owned centre run by the Budapest Methodological Centre of Social Policy and its Institutions (BMSZKI). The headquarters and the fundamental part of the services provided by the organization are located in a building built at the beginning of the $20^{\text {th }}$ century. The building was originally intended as a house for workmen coming to the capital; the reason it was built was the development of the city and shortage of adequate residential spaces. The construction was started in 1910; and in 1912, a cheap workers' hotel was established there. At the beginning, it had 396 small single bedrooms and 42 common sleeping rooms as well as a dining room and a kitchen. During the First World War, it performed the function of a war hospital; during the Second World War, it was turned into a barracks and then again into a hospital for wounded soldiers. From 1950 to 1980, it was a workers' hotel again.

After almost 100 years, the building was renovated (in 2000-2002) and, as a result, rooms and standards were adapted to services provided to people in a difficult life, economic, and residential situation. On each of the three floors where rooms are located (operating as a hostel - you may receive accommodation after the qualification procedure, for a small fee), sanitary facilities were added as well as shower rooms and shared kitchens. The hostel is divided into a space for men, a space for women, and a mixed space, where couples may stay together. On the ground floor and on the underground level, there is a night shelter, a warming room, and rooms for people requiring help, i.e. elderly people, people with diseases (there is a medical centre and rooms for patients in BMSZKI), pregnant women, and victims of violence. The building also houses the central office of BMSZKI; it occupies administrative rooms located on almost each floor, from typical office rooms to contact stations for people coming for advice (e.g. career advice), a food distribution centre, rooms for staff on duty etc. 
Forms of aid provided in BMSZKI are reflected in the presence of rooms for various purposes in the building, which is approx. 3,000 sq. m. Labyrinths of corridors and the division into separate parts and floors (the building has the shape of the letter E) make one think firstly of a metaphor of a ladder with separate access levels. The institution operates according to the following pattern: a person may, but does not have to (it depends on their individual needs), follow a way beginning from the lowest level, i.e. the cellar, where the warming room is, through temporary shelters useful in periods of crisis, i.e. night shelters (ground floor), up to rooms (floors 1-3). Despite the ladder-like manner of operation which serves the possibility of providing comprehensive support (due to several co-existing factors, such as age - material situation - condition of health - others), the space of the building seems complicated and difficult to understand. The building consists of several wings and has internal staircases; functional layouts in the wings are repeated (such as residential spaces plus kitchens). That gives an impression of multiplication and hugeness. It also brings other associations - metaphors of a labyrinth and roots. In BMSZKI, the right to privacy is also graded, such as the right to manage one's own space. The internal arrangement of BMSZKI reflects the nature of the separate parts of the building and the attitude to aid and life crises. The rooms located in the lowest part are uniform and their furniture is limited to simple bunk beds and lockers for private things in the night shelter, and long tables in the warming room. On the higher floors of the hostel, it is easy to notice the division into categories of space, i.e. a common, but sociofugal space (e.g. a kitchen with a food preparation place with no dining room inside or nearby), a non-descript no-man's-land, which is a typical sociofugal space, almost no-space at all (it includes corridors as typical communication routes, only for moving), and a private space including rooms which may not be called sociopetal, as they are personal mini-flats. Manifestations of privacy may be found on the doors of rooms opening onto the corridor (as on the women's floor); they are decorated with newspaper cuttings, stickers (with views, animals, no entry signs, pacifist, anarchist, and religious signs, or mottoes), curtains hung on the doors from the outside, doormats, pot plants standing near the doors. The doors are very personalized; they are not signs but symbols or maybe even a metonymy of the people who have found shelter behind them. It seems surprising, but such a manifestation of individuality in the sociofugal space of a corridor does not make it inclusive; quite the opposite, it defines borders between an individual and other users even more clearly. However, BMSZKI operates as a hostel, i.e. a residential building with rooms for rent for a year or longer. As a result, the feeling of domesticity and "homeness" arises, which is symbolized by those colourfully decorated doors. Despite that, even if we seek an analogy of those actions to personal expressions observed e.g. on balconies or sometimes in staircases of multi-storey buildings and blocks of flats, manifestations of personality in BMSZKI simply seem to hyperbolize individuality. Perhaps that is a sign of some- 
thing deeper, i.e. a reaction of the residents to unifying activities, i.e. procedures and formalities.

Sociopetal spaces in BMSZKI include the warming room and the day rooms which also perform the role of TV rooms, meeting rooms, or special event rooms and, as such, they are flexible. However, flexibility in BMSZKI is directed at separating oneself, as integrating and inclusive community actions are phenomena, something special, i.e. the special events referred to above.

\section{Krakow and Gdansk}

We are going to discuss these examples together as they were both established to the order of the organizations who run them (as opposed to BMSZKI).

The first case refers directly to people experiencing homelessness and at risk of homelessness in combination with poverty (Krakow) and it is an institution providing emergency aid. The second case refers to more groups at risk of exclusion (Gdansk). These are not only people experiencing or at risk of homelessness; the fundamental function of the centre is residential combined with support.

\section{Krakowskie Dzieło Pomocy św. Ojca Pio}

Krakowskie Dzieło Pomocy św. Ojca Pio (St. Padre Pio Krakow Aid Centres) is an internal unit of the Order of Friars Minor Capuchin of the Province of Krakow and a public benefit organization. Since 2004, it has conducted various activities supporting homeless people, people at risk of homelessness, and the poor. As a part of this, two Aid Centres operate, as well as a continuously increasing network of supported and protected flats located across the city, which will soon be supplemented with mixed flats, where people with the experience of homelessness will co-habit with "home-having" people.

In 2010, the first Aid Centre was opened on Loretańska street, where social workers, job advisers, psychiatrists, and therapists provide services and support and where self-help support groups operate. However, it is the second Aid Centre (called by us Centre 2 for the purposes of this work) opened in 2013 at Smoleńsk street 4 that is worth particular attention in the context of our discussion. The surface area of that modern building is over 2,400 sq. m.; various forms of support are provided on its 4 floors. The building is maintained using the funds collected by the organization and is a private property. The layout of the building is a cuboid which is empty in the middle. The center of the building is empty and on the ground floor there is a glazed patio. The motif of opening to the middle through the glass is repeated on the next floors. Around that glass light-penetrated tunnel, separate rooms and functions are located concentrically. Two staircases may be used to move around the building, i.e. one for clients and staff, and one for guests of the institution or formal stakeholders. 
The building may be entered through three entrances located on the front wall. The first entrance, closer to the gate from the street, leads to the patio and the kitchen. Both those places are open for people from the outside, i.e. everyone who wants to enter. As a result, people living nearby and those who know Krakow also come to the kitchen to have a meal for a very low price. Therefore, both of those spaces are open, public, and - due to the function they perform - sociopetal.

The kitchen operates as a part of Kuchnia Społeczna im. S. Samueli (The Sister Samuela Community Kitchen) and is run by the Felician Sisters; it is a continuation of operations conducted in the past in the place where Centre 2 was established. On the ground floor, the aforementioned spacious and glazed patio is also located, where people may rest, sit, and have a cup of hot tea (free access). Everyone may enter; no one is asked about anything. No special visible integrating or intervention actions are taken with regard to people who are staying there. In the patio, there are only chairs placed around along the glazed walls; sometimes a pot with plants is also put there. The centre of the room is empty; on the wall facing the entrance, which, as a result, may be interpreted as the central wall of the whole building, the figure of Padre Pio is exhibited.

The second entrance is for typical clients, i.e. people coming for specific help, and benefactors. Clients pass a closed and glazed porter's box, which is a certain "inspection" point for people using the services provided inside the building. They are directed to a day room on the ground floor, which is adjacent to the patio, the $1^{\text {st }}$ floor (a medical clinic of Stowarzyszenie "Lekarze Nadziei" - the "Doctors of Hope" Association), or the $2^{\text {nd }}$ floor (where computer rooms are located, as well as rooms for careers advice services and other forms of individual support).

The day room is for deeper integration; it serves as a starting-point of aid, support, and therapeutic contact, which is established over time by staff.

The third entrance, which is the furthest from the street and the gate, leads to a washing room, a laundry room, and a changing room. At that entrance, there is also a reception room. To use those functions, one has to go down to the cellar, where that aid is provided. The rooms are staffed with volunteers and employees who control all parts (from the washing room to the laundry), which are placed concentrically around their internal porter's box.

On the last floor, over the medical clinic of the Doctors of Hope, administrative rooms are located for employees and volunteers of Dzieło Pomocy św. Ojca Pio.

What is important, the Aid Centres have a specially designed system of monitoring clients. It is a special database referring to tasks performed by the organization. In that database, each client has their own profile, which contains information such as medical or therapeutic appointment dates, use of laundry, washing room, or changing room, dates of meeting with an advisor etc. Full access to the database is granted only to selected people, who are the highest in the staff hierarchy; other specialists receive only the information referring to their field of operation. They are obliged to enter that information in the database. Doctors are excluded from the 
system apart from a report on the frequency of appointments and dates of appointments; medical information is recorded in medical documentation which is protected in a special manner. That instrument, the software and the database, together with the placement of staff at specific "check points" at main entrances, in sanitary rooms in the cellar, and in the clinic, as well as on the last floor under the glazed roof, from where staff may look through the glazed centre down to the patio and are able to observe what is happening in the corridors, is a modern expression of panoptism. The building and its internal layout, which is concentric and cylindrical, resembles a hierarchic spiral: authorities are placed at the entrance and at the top, which is the best expression of symbolic and literal control; they also have special internal software, which weaves around that spatial functional layout like a net. That software may be described metaphorically as the blood circulation system which nourishes the efficient body of the institution.

For that reason, the building meets the requirements of the intelligent construction model. Admittedly, it is still based on "analogue" means, that is to say, human powers; however, the conception of Centre 2 at the information, communication, and management levels is very efficient and effective, bearing a resemblance to a programmed and highly-efficient device. Some people speak about a residential device; in the case of Centre 2, we should speak about "a machine for aid". The building makes a very positive impression owing to the use of natural light; it is constructed based on eco-friendly technologies (such as photovoltaics). Despite its surface area of over 3,000 square metres, it does not seem large as a result of the cylindrical and concentric layout. The construction is compact and compatible. In addition, the layout seems logical and, what follows, reasonable; it is easy to find your way there.

The placement of separate functions in the described building is highly symbolic and, as in the case of BMSZKI, proves the existence of a hidden curriculum: in Centre 2, physical dirt is eliminated underground. It is only from there that one may go higher, to the ground floor, to receive medical assistance; at the highest level available to clients, they start a "new" life (career advice, training, therapy etc.). At the entrance, visitors may receive a meal or, if they come to use one of the services provided, they are greeted by the figure of Padre Pio, the patron of the whole initiative, which is a certain punctum of that space (ethically and iconographically).

The centre is modern; it has been constructed and designed specifically for its purposes, i.e. it realizes the assumptions and expectations of those managing the organization. It is hardly flexible with regard to the interpenetration of separate levels. However, it is more flexible horizontally, including on the medical clinic level, as the purpose of certain rooms may be changed, e.g. general-purpose surgeries, and medical devices may be disassembled and moved to a different place. As a result, a gynaecological surgery may become a gastrological or ophthalmological one and vice versa. Despite that, most of the public spaces in the building are sociofugal. In general, they include only corridors as there are no other public 
spaces in Centre 2 for clients apart from the patio and the day room. Corridors are only for moving along and they were designed mainly for the staff, as the clients come directly to an appointment or to classes and go to a specific surgery or to rooms on a specific floor at once. For example, an appointment in a clinic looks as follows: there are chairs for patients only in front of the reception desk - it is there that they wait for their turn to go into a surgery, as there are no chairs outside surgery doors. Patients come to the clinic at an appointed hour, which is strictly observed and noted in the system. Therefore, each person going into the clinic has an appointment or comes to make an appointment; their visits have a specific purpose. It is similar on the floor above, that is to say in the part with classrooms, therapy rooms and offices, where there are no chairs outside on the corridor either. Each person coming to a class or to an appointment comes to receive a specific service at a specific time. No one spends time in that building in any way other than dealing with a specific and pre-defined matter.

\section{Dom na Dolnych Młynach (DDM) in Gdansk}

The last of the discussed cases differs from the other ones as it tries to go beyond traditionally understood institutionalized support. It is a residential building at Dolne Młyny street 4 in Gdansk, which consists of 25 council flats for people in a special situation. It is a city initiative; however, it was started in cooperation with many Gdansk non-governmental organizations with regard to the assumptions and programme. The architectonic design stands out against other investments of that type because, among other things, eco-friendly solutions have been used there and the building itself is mostly constructed of wood. It has a modern and minimalist architecture, fitting well into its surroundings. It is worth emphasizing that this project is a part of the "Gdansk Programme of Social Housing for people/families at risk of social exclusion for 2016-2023" (https://bip.gdansk.pl/subpages/ akty_prawne/pliki/2016/URM_2016_7_867.pdf).

Beneficiaries of the project include those Gdansk residents who may be qualified as fit for receiving a council flat; however, they should also meet another condition, i.e. they should be participants in various social support programmes organized by the Municipal Social Care Centre in Gdansk and non-governmental organizations. As a result, the present beneficiaries of the House make a very diverse group, i.e. single mothers, disabled people, people leaving foster care, lonely or elderly people, ex-convicts, and people who were recently homeless.

The idea of DDM is to provide a stable form of residence which would not be limited in time only to the period of specific projects which are usually short- or medium-term (from a year to three years). A flat in DDM is granted not for the period of the project, but permanently. It is accompanied with support in the form of a programme, which is flexible, adapted to individual needs and the needs of the whole community. It is supervised by assistants who help residents design the 
support and also play the role of animators. The support is offered at the House. The assistants have a flat on the ground floor at their disposal where, during the project, they run an office, a place of support, and a contact centre. When the project and the support programme end, they will close the centre and leave the flat for another resident.

It is the DDM residents themselves who decide when and in what form they want to use the offered forms of cooperation with the assistants, the main purpose of which is to provide adequate forms of aid tailored to the needs of each resident; to such an extent that the contracts of the assistants provide for flexible working time. As a result, the assistants may adjust (to a certain extent) to activities and residents and make appointments at a time convenient for the residents. Therefore, they have no fixed working time. Staff activities are also supposed to support the integration of the community of residents.

Each year, the residents pay higher rent up to the full rate per metre in a council flat adopted by the authorities and councillors of the city of Gdansk; as the rent increases, the support of assistants will be lower and lower each year (the whole process is supposed to last for approx. 8 years). The support will become less intensive, narrower, up to a complete withdrawal, and the residents will be left in the building as entirely socially "provided" individuals (as far as possible). The process implemented in that institution consists, therefore, in a gradual parting with support with a simultaneous reinforcement of the residents in their place, in their homes. After that period, they will be able to move out, change their place, go and live somewhere else. They have full rights and choice in that area.

DDM has a common day room which has been arranged by the residents themselves and which is used e.g. for a New Year's party or larger family events. Close to the house, there are a playground, some benches, and a shelter; those are additional elements which facilitate integration of the residents, including integration with people from the neighbourhood. There used to be no such place for children in the area; that gap has been filled by the playground next to DDM and, as a result, it is visited by other residents from the area. Therefore, the integration process may include not only the community residing in the building, but also the community of the neighbours.

What is important, recruitment to DDM has been performed with the support of specialists who conducted various aid programmes; proposed candidates recommended to the House were participants in those programmes. They had to meet certain criteria. However, none of them knew who their neighbours were; the same applied to the local community. There was no internal animation either; no emphasis was put on those elements from the residents' biographies which would transform the community into a support group or a self-help group due to their histories. What was emphasized was the natural development of neighbourly relationships: it depends only on the decision of the residents how much they want to integrate, what to tell about themselves and to whom, and what type of relation- 
ships they want to establish; it is only their decision whether they want the assistants to help them in that matter or not.

The layout of the 3-storey building resembles a classic multi-family block of flats which is, however, quite small. On each floor, there are flats of various, but quite similar, sizes with a common part on the ground floor, i.e. the aforementioned two-part day room with a kitchen annexe. As has already been mentioned before, one of the ground floor flats is used as the assistants' office, but, after the end of the programme, it will also be converted into a flat.

In that building, support is somehow "reversed" as compared to the most frequent standard where it is a client who goes to a specialist centre to seek help. In DDM, support comes to clients, to their place of residence, and there is a special space for that purpose. The only common spaces are those which we have already mentioned, i.e. the day room, the playground, the yard with the car park, the shelter, the hall, and the corridors. The most sociopetal places include the day room and the playground. However, the day room equipment (apart from kitchen devices) is very flexible; tables, coffee tables, and chairs may be moved to arrange a space reflecting the needs and the type of meeting to be held. The DDM building is a house in the strictest sense of that word, where support acquires its proper sense and is not replaced or masked with control.

DDM may be compared to a tree or a village: it carries the potential for its residents of growing roots and regaining stability and of a future built together with others who are equal, among other things, by having a right to common, public, and private spaces.

\section{Conclusions}

The aid institutions for homeless people selected by us represent models of space organization which are stretched between the extreme cases of the spectrum of sociopetal and sociofugal places, also in relation to various forms of flexibility (including no flexibility at all). They are interesting examples of architectonic designs, starting from a building adapted for the needs of people in the crisis of homelessness (Hungary) to buildings which have been designed especially for their purposes (Centre 2 in Krakow). In the Hungarian case, the original layout may be changed by the staff and the residents only on the level of aesthetics and symbols to emphasize new functions and new purposes realized in the old space as well as new functions and purposes of the space itself. Any change on a deeper, constructional, level would require reconstruction, which is impossible. On the other hand, however, the Polish examples (Krakow and Gdansk) are construction and aid designs which have been made to the order of the organizations. Those organizations interpret homelessness, crisis, and aid through their orders, in their own manner. 
Their ideas have been translated into a spatial "text" where the buildings have become embodiments of the organizations' spirit and idea (ref. to Hall, Hall 2001).

Thus, BMSZKI is mostly a sociofugal space, barely flexible, panoptic and total to a certain extent, which is also emphasized by individual activities, which we propose to treat as a manner of escape from the internal regime ruling there (as it rules in each institution of that type). There is formalism there demonstrated with a dispersion of staff and administration offices at each function in each wing: the administration operates behind closed doors and counters on almost each level where residents live and where clients come. As a result, a message is sent saying: "We are available but also vigilant. We are close but we do not become involved. We are on duty and on watch".

Centre 2 in Krakow, like BMSZKI, provides support understood as comprehensive services which are closely integrated owing to one space where those services are located and treated as complementary to each other. Support is provided in a single, but multi-threaded space, which is complex, but easy to perceive owing to the concentric structure of the whole Centre 2 building. The organization performs residential functions, like BMSZKI, but residential spaces are located in various places in the city. Therefore, the accumulation of tasks in a single place is not total as in the case of the institution from Budapest. However, the organization as an entirety represents a total institution which is panoptic in the classic meaning. Panoptism in BMSZKI is dispersed around the whole building (staff offices are located on each floor and almost in each part of the building); in Centre 2, as we have described, the observing authorities are present at the initial stage and accompany the subsequent stages of support by penetrating everything (like light coming down through the glazed ceiling and walls). It is worth mentioning that since the Aid Centres are initiatives of a religious order taken in cooperation with lay believers who have chosen Padre Pio, a Catholic saint, as the patron of their institution, the symbol of light coming from above and, in addition, falling centrally on the figure of the patron, which is also placed centrally as it is in front of the main entrance, may also be interpreted in categories of religious symbols. That path in encoding the hidden curriculum in the Aid Centre 2 would not be an overinterpretation.

It would seem, on the other hand, that the space of DDM in Gdansk is also barely sociopetal; however, it is a typical block of flats, where each resident leads their life in a separate flat and staying in common spaces is limited as much as possible. It must be remembered that some residents have experience of living in various institutions where there is almost no intimacy and privacy at all. Therefore, they may display a mechanism of building their own nest far from others, and they may not want the presence of others. Moreover, the impression that DDM is sociofugal may be questioned, which the words spoken by the Mayor of Gdansk, the initiator of the House, suggest. In that building, efforts are made to provide personal space to people with difficult life experiences. When they enter DDM, they are in the space 
which may become their asylum for a long time or even permanently (each of those solutions depends only on them). To make it possible, to realize that concept of providing aid by providing a home, a different space has become sociopetal. We mean the space of the city - Gdansk, which is a space in the macro- and meta-sense. Gdansk is a symbol of a metropolis which treats its residents in an equal and inclusive manner, considering the opinions of its residents. That idea of a city is, in our opinion, one of the more important points of reference in creating other spatial arrangements which are flexible and open to evolution.

As we saw in the first part of this work, institutions as places and spaces in the physical sense are embodiments of a cultural-social hidden curriculum (by using the whole available symbolic and metaphorical apparatus). Therefore, they may be seen as materializations of specific ideas; they are three-dimensional representations of ideas. That influences the people using a place: in the case of the selected institutions that means the staff, clients, guests, and decision makers. That is what the phenomenon of genius loci consists in, a place and, at the same time in our opinion, an institution: it is a force of influencing people and forming them. As Douglas wrote (2011: 116): "institutions produce labels, a feedback is provided in the form of Merton's self-fulfilling prophecy. Labels bring an element of stability to the constantly changing social life and, to a certain extent, they create the reality they refer to". If it is so, it should be of key importance to design a space for support institutions in the manner which would meet the condition not only of universal or environmental design, but also a design based on the User Experience method, including User-Centred Design, which realizes the paradigm of equal opportunities as well as equal treatment of different members of a community and their needs.

In Poland, in the context of designing support institutions addressed towards homeless people, we may refer to a legal act concerning threshold requirements which should be met by night shelters, shelters, and warming houses. It is the Regulation of the Minister of Family, Labour, and Social Policy of 27 April 2018 on minimum standards of night shelters, shelters for the homeless with care services, and warming houses (Dziennik Ustaw of 2018, item 896). It provides for e.g. the size of space for separate functions and which functions should be performed: from sleeping rooms to dining rooms, storage areas, laundry rooms, offices, and computer rooms. A dining room is often mentioned there in combination with a day room, as a space with a changing purpose. The Regulation also describes furniture; it contains a provision saying that there should be a free access to beds.

The minimum requirements described in the Regulation do not include guidelines related to a proper approach to space; they do not refer to fundamentals of proxemics, which could be stated as follows, as good foreign practices show:

Empathy and User-centered Design: For the designer, perhaps one of the most challenging aspects of shelter programming is (...) understanding a homeless person's point of view. The typical homeless shelter resident is un- 
dergoing a crisis that has resulted in a change of lifestyle and the loss of familiar surroundings. This experience can effect a dramatic change in a person's world view, impacting their needs and priorities. (...) As many homeless persons have been abused or attacked, they are sensitive to seating locations that expose their backs and places that prompt feelings of vulnerability. Strategically orient seating so users are facing out from sheltering walls. Think carefully about spatial volumes that may be overwhelming. Provide 'retreat' spaces. Homelessness results in fragile personal identity. Using name tags, not numbers, that assign temporary ownership to beds or living spaces can help preserve a sense of self and individuality. One of the largest mental challenges of homelessness is boredom. Out of sync with the schedule of work and family, idleness can exacerbate feelings of worthlessness and disconnection. Provide reading materials, newspapers and, as appropriate, gatherings or games. Balconies (...) may also invite suicide attempts. Separate restrooms for staff should be provided to shield them from getting lice or scabies, and increase their length of service. Bedroom furniture should not be constructed of wood as bedbugs can burrow into the wood grain and become impossible to eradicate" (Pable br. r. w.: http://www.informedesign...).

However, it should be remembered, as in Douglas (2011), that each institution, whether meeting the requirements of the User-Centred Design or not, "controls the memory of its members" (ibidem: 131). Individuals share common sense also on the level of making decisions as a part of institutions, which are socio-cultural products and, therefore, a certain emanation of collective reason and emotions.

\section{References}

Basińska A., Jeran A. (2016) Dom tylko z nazwy. Projektowanie partycypacyjne (w) przestrzeni wspólnej domu dziecka in: Socjologia zamieszkiwania. Narracje, dyfuzje, interwencje, M. Jewdokimow, M. Łukasiuk (eds.), Warszawa, Wydawnictwo UKSW: 97-106.

Bystroń J. S. (1976) Dzieje obyczajów w dawnej Polsce. Wiek XVI-XVIII, vol. 1, Warszawa, PIW.

Cobel-Tokarska M. (2011) Przestrzeń społeczna: świat - miasto - dom in: Krótkie wykłady z socjologii. Przegląd problemów i metod, A. Firkowska-Mankiewicz, T. Kanash, E. Tarkowska (eds.), Warszawa, Wydawnictwo ASP: 45-62.

Dickinson J. I., Stafford K., Klingenberger K., Bicak N., Boyd Ch., Dreyer M. (2017) The Design and Testing of a Student Prototyped Homeless Shelter, "Journal of Interior Design", 3: 53-70.

Douglas M. (2011), Jak myślq̨ instytucje, transl. by O. Siara, Warszawa, Wydawnictwo Naukowe PWN. 
Dymnicka M., Rozmarynowska K. (2006) Architektura szkoły i jej społeczne funkcje in: Pedagogika miejsca, M. Mendel (ed.), Wrocław, Wydawnictwo Naukowe DSWE TWP we Wrocławiu: 251-261.

Foucault M. (1998) Nadzorować i karać. Narodziny więzienia, transl. by T. Komendant, Warszawa, Fundacja Aletheia.

Goffman E. (2005) Piętno. Rozważania o zranionej tożsamości, transl. by A. Dzierżyńska, Gdańsk, Gdańskie Wydawnictwo Psychologiczne.

Goffman E. (2011) Instytucje totalne. O pacjentach szpitali psychiatrycznych i mieszkańcach innych instytucji totalnych, transl. by J. Łaszcz, Sopot, Gdańskie Wydawnictwo Psychologiczne.

Hall E. T. (1976) Ukryty wymiar, transl. by T. Hołówka, Warszawa, Państwowy Instytut Wydawniczy.

Hall E. T. (1987), Bezgłośny język, transl. by. A. Skarbińska-Zielińska, Warszawa, Państwowy Instytut Wydawniczy.

Hall E. T., Hall R. M. (2001) Czwarty wymiar $w$ architekturze: studium o wpływie budynku na zachowanie człowieka, transl. by R. Nowakowski, Warszawa, MUZA.

Kępski C. (1993) Towarzystwa dobroczynności w Królestwie Polskim (1815-1914), Lublin, Wydawnictwo Uniwersytetu Marii Curie-Skłodowskiej.

Kuźma I. B. (2015) Domy bezdomnych. Badania sytuacji kryzysowych, Łódź, Wydawnictwo Uniwersytetu Łódzkiego.

Lipiński S. (2010) Zakłady dobroczynne i domy poprawy w dawnej Polsce, Łódź, Wyższa Szkoła Edukacji Zdrowotnej.

Mazur E. (1999) Dobroczynność w Warszawie XIX wieku, Warszawa, IAiE PAN.

Mendel M. (ed.) (2006) Pedagogika miejsca, Wrocław, Wydawnictwo Naukowe DSWE TWP we Wrocławiu.

Nawratek K. (2013) Przestrzeń, Miejsce, Terytorium: Carl Schmitt i miasto postneoliberalne, "Władza Sądzenia”, 2: 11-20.

Nowel-Śmigaj A. (2012), Panopticon a oligopticon. Czy strzeżone znaczy zastrzeżone?, “Architektura. Czasopismo Techniczne", 1 (109): 27-37.

Pable J. (no publication date) Design Response o Homelessness, "Implications. A Newsletter by Informe Design", 4 (7), https://www.informedesign.org/_news/jul_v04r-p. pdf [accessed: 2.05.2019].

Piątkowska K. (2016) Estetyczne i etyczne aspekty wspótczesnej antropologii, Łódź, Wydawnictwo Uniwersytetu Łódzkiego. 
Raś D. (2011) Rodziny ubogie i przestępczość od XVI do XX wieku. Warunki życia, badania psychologiczno-społeczne, dobroczynność $i$ wychowanie młodzieży, Kraków, Oficyna Wydawnicza "Impuls".

Sadoń-Osowiecka T. (ed.) (2015) Miejsce - przestrzeń - krajobraz. Edukacyjne znaki, Gdańsk, Wydawnictwo Uniwersytetu Gdańskiego.

Sikorski W. (2013) Proksemika klasy szkolnej - ukryty wymiar edukacji, "Edukacja”, 3 (123): 91-105.

Skałbania B., Gretkowski A. (2016) Szpital jako miejsce (nie) przyjazne dziecku - rola proksemiki w procesie leczenia, "Rocznik Towarzystwa Naukowego Płockiego", VIII: 411-426.

Trzeciak K. (2018) Materialistyczna krytyka literacka: niedokończony projekt, "Śląskie Studia Polonistyczne", 2 (12): 167-180.

Walsh C. A., Beamer K., Alexander C., Shier M. L., Loates M., Graham J. R. (2010) Listening to the Silenced: Informing Homeless Shelter Design for Women through Investigation of Site, Situation, and Service, "Social Development Issues", 3: 35-49.

\section{Online resources}

Rozporządzenie Ministra Rodziny, Pracy i Polityki Społecznej z dnia 27 kwietnia 2018 roku w sprawie minimalnych standardów noclegowni, schronisk dla osób bezdomnych, schronisk dla osób bezdomnych z usługami opiekuńczymi i ogrzewalni http://prawo.sejm.gov.pl/isap.nsf/DocDetails.xsp?id=WDU20180000896 [accessed: 3.12.2019].

Uchwała Nr XXXI/867/16 Rady Miasta Gdańska z dnia 24 listopada 2016 roku https://bip.gdansk.pl/subpages/akty_prawne/pliki/2016/URM_2016_7_867.pdf [accessed: 3.12.2019].

https://www.bmszki.hu/en/erasmus2/about-project [accessed: 3.12.2019].

http://niepelnosprawni.gov.pl/art,54,projektowanie-uniwersalne [accessed: 10.05.2019].

https://rewitalizacja.uml.lodz.pl/rewitalizacja/wybrane-projekty-rewitalizacji/ projekt-pilotazowy-ii-2017-2019/ [accessed: 3.12.2019]. 